\title{
MEKANISME PASAR DALAM PERSPEKTIF ISLAM \\ (KAJIAN PEMIKIRAN ABU YUSUF)
}

\author{
Moh. Agus Sifa' \\ Institut Agama Islam Al Hikmah Tuban \\ agusagus58@gmail.com
}

\begin{abstract}
Market Mechanisms in the development of the economy there have been many innovations carried out by modern economic figures. In this case the market mechanism that develops a lot is the difference between the modern mechanism with the mechanism of Islamic economic thought, where Islamic economic thinkers first introduced the market mechanism especially by Islamic economic thinker Abu Yusuf, recorded as the earliest scholars who began to allude to the market mechanism. In terms of market mechanism Abu Yusuf gives a different view to public opinion, where high prices do not mean there is scarcity of goods and cheap prices do not mean abundant goods, but there are other variables that determine price formation. Abu Yusuf also opposed the authorities in setting prices. But he also allows price intervention in the market in certain circumstances. Abu Yusuf said that the price level does not only depend on demand but also on the strength of supply. Therefore, an increase or decrease in the price level does not necessarily have to be related to an increase or decrease in production alone.
\end{abstract}

Keywords: Market mechanism, Abu Yusuf Economic Thought

\section{Pendahuluan}

Dalam perkembangan dunia ekonomi islam semakin tahun semakin berkembang yang diiringi dengan kemajuan teknologi yang tidak bisa dipisahkan dari kehidupan kita. Banyak sekali inovasi yang terus dikembangkan oleh perorangan maupun perusahaan dalam meningkatkan persaingan bebas pada zaman saat ini. Perkembangan saat ini perlu adanya keseimbangan antara ekonomi umum dan ekonomi islam uang secara tidak langsung saling berkaitan dan saling membutuhkan. Maka dari itu kita perlu membuat perkembangan ekonomi dengan menggabungkan ekonomi umum yang tidak lepas dari ekonomi islam untuk mebatasi masalah masalah yang telah diatur dalam hukum islam.

Masalah yang timbul dalam ekonomi sangat banyak sekali sehingga kita perlu membagi beberapa bagian sehingga kita dapat fokus mengambil masalah tersebut dalam 
dunia ekonomi. Apalagi masalah mengenai mekanisme pasar yang sering terjadi dalam kehidupan kita bahkan kita tidak jarang melakukan hal tersebut.

Kemunculan masalah masalah ekonomi dapat disampaikan bahwa ada beberapa pesan moral Islam dan pencerahan teori pasar, dapat dikaitkan sebagai bagian dari reaksi penolakan atas sistem sosialisme dan sekularisme. Meskipun tidak secara keseluruhan dari kedua sistem itu bertentangan dengan Islam. Namun Islam hendak menempatkan segala sesuatu sesuai pada porsinya, tidak ada yang dirugikan, dan dapat mencerminkan sebagai bagian dari the holistic live kehidupan duniawi dan ukhrowi manusia.

Oleh sebab itu, sangat utama bagi umat Islam untuk secara kumulatif mencurahkan semua dukungannya kepada ide keberdayaan, kemajuan dan kecerahan peradaban bisnis dan perdagangan. Islam secara ketat memacu umatnya untuk bergiat dalam aktivitas keuangan dan usaha-usaha yang dapat meningkatkan kesejahteraan social.

Berdagang adalah aktivitas yang paling umum dilakukan di pasar. Untuk itu teksteks Al Qur'an selain memberikan stimulasi imperative untuk berdagang, di lain pihak juga mencerahkan aktivitas tersebut dengan sejumlah rambu atau aturan main yang bisa diterapkan di pasar dalam upaya menegakkan kepentingan semua pihak, baik individu maupun kelompok.

Konsep Islam menegaskan bahwa pasar harus berdiri di atas prinsip persaingan bebas (perfect competition). Namun demikian bukan berarti kebebasan tersebut berlaku mutlak, akan tetapi kebebasan yang dibungkus oleh frame syari'ah. Dalam Islam, Transaksi terjadi secara sukarela (antaradim minkum/mutual goodwill, Sebagaimana disebutkn dalam al-Qur'an surat An Nisa' ayat 29.

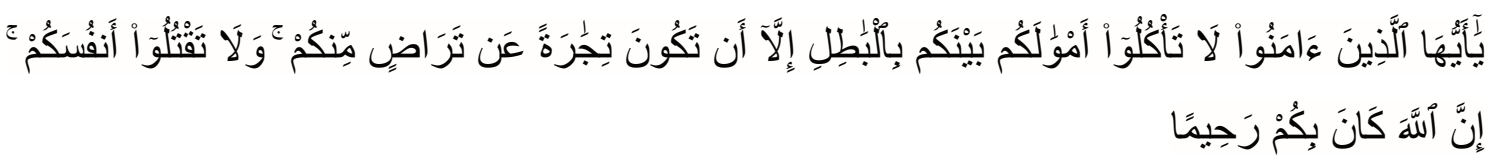

Artinya : Hai orang-orang yang beriman, janganlah kamu saling memakan harta sesamamu dengan jalan yang batil, kecuali dengan jalan perniagaan yang Berlaku dengan suka sama-suka di antara kamu. dan janganlah kamu membunuh dirimu. Sesungguhnya Allah adalah Maha Penyayang kepadamu.(QS. An Nisa' : 29) 
Selanjutnya pasar yang adil akan melahirkan harga yang wajar dan juga tingkat laba yang tidak berlebihan, sehingga tidak termasuk riba yang diharamkan oleh Allah SWT. sebagaimana ayat berikut:

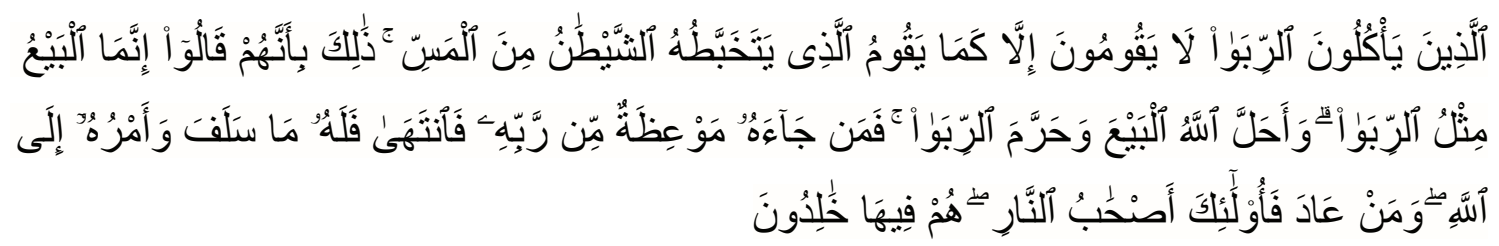

Artinya: Orang-orang yang makan (mengambil) riba tidak dapat berdiri melainkan seperti berdirinya orang yang kemasukan syaitan lantaran (tekanan) penyakit gila. keadaan mereka yang demikian itu, adalah disebabkan mereka Berkata (berpendapat), Sesungguhnya jual beli itu sama dengan riba, padahal Allah Telah menghalalkan jual beli dan mengharamkan riba. orang-orang yang Telah sampai kepadanya larangan dari Tuhannya, lalu terus berhenti (dari mengambil riba), Maka baginya apa yang Telah diambilnya dahulu (sebelum datang larangan); dan urusannya (terserah) kepada Allah. orang yang kembali (mengambil riba), Maka orang itu adalah penghunipenghuni neraka; mereka kekal di dalamnya. (QS Al Baqarah: 275)

Dalam pada itu, transaksi yang dilakukan secara benar dan tidak masuk dalam riba dalam mencari keutamaan Allah bahkan mendapat dukungan yang kuat dalam agama.

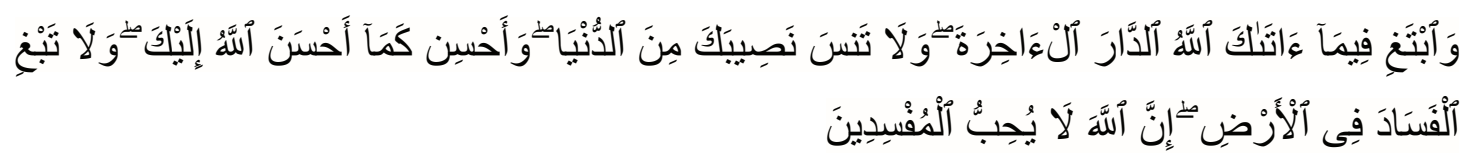

Artinya : Dan carilah pada apa yang telah dianugerahkan Allah kepadamu (kebahagiaan) negeri akhirat, dan janganlah kamu melupakan bahagianmu dari (kenikmatan) duniawi dan berbuat baiklah (kepada orang lain) sebagaimana Allah telah berbuat baik, kepadamu, dan janganlah kamu berbuat kerusakan di (muka) bumi. Sesungguhnya Allah tidak menyukai orang-orang yang berbuat kerusakan.

Masalah Mekanisme Pasar telah banyak dibahas oleh tokoh tokoh pemikir ekonomi Islam atau pun tokoh tokoh ekonomi modern. Salah satu pemikir ekonomi islam yang membahas mekanisme pasar adalah abu yusuf. Abu yusuf tercatat sebagai 
ulama terawal yang mulai menyinggung mekanisme pasar. ${ }^{1}$ Kajian ini akan berupaya menjelaskan tentang konsep mekanisme pasar dalam persepektif islam dan konsep mekanisme pasar menurut abu yusuf.

\section{Mekanisme Pasar secara umum}

Dalam Kamus Besar Bahasa Indonesia disebutkan bahwa pasar adalah tempat orang berjual beli. Sedangkan menurut istilah, Pasar adalah sebuah mekanisme pertukaran barang dan jasa yang alamiah dan telah berlangsung sejak peradaban awal manusia. ${ }^{2}$ Sedangkan menurut pendapat lain dalam kajian ekonomi, pasar adalah suatu tempat atau proses interaksi antara permintaan (pembeli) dan penawaran (penjual) dari suatu barang/jasa tertentu, sehingga akhirnya dapat menetapkan harga keseimbangan (harga pasar) dan jumlah yang diperdagangkan. Jadi setiap proses yang mempertemukan antara penjual dan pembeli, maka akan membentuk harga yang akan disepakati oleh keduanya. ${ }^{3}$

Menurut penjelasan lain Pasar adalah suatu tempat di mana pembeli dan penjual bertemu untuk membeli atau menjual barang dan jasa atau faktor- faktor produksi. Di dalam bahasa sehari-hari pasar pada umumnya diartikan sebagai suatu lokasi dalam artian geografis. Tetapi dalam pengertian teori ilmu ekonomi mikro cakupannya adalah lebih luas lagi. Dalam teori ekonomi mikro pasar meliputi juga pertemuan antara pembeli dan penjual di mana antara keduanya tidak saling melihat satu sama lain (misalnya antara importer karet yang bertempat tinggal di Amerika dan importer karet di Indonesia) yang melakukan transaksi jual beli melalui telex.

Dari beberapa pengertian tersebut, maka pasar dapat diartikan sebagai suatu tempat terjadinya mekanisme pertukaran barang atau jasa oleh penjual dan pembeli untuk menetapkan harga keseimbangan serta jumlah yang diperdagangkan.

Mekanisme pasar adalah terjadinya interaksi antara permintaan dan penawaran yang akan menentukan tingkat harga tertentu. Adanya interaksi tersebut akan mengakibatkan terjadinya proses transfer barang dan jasa yang dimilki oleh setiap objek

\footnotetext{
${ }^{1}$ Adiwarman Azwar Karim, Sejarah Pemikiran Ekonomi Islam (Depok: PT RajaGrafindo Persada, 2017), 208

${ }^{2}$ Pusat Pengkajian dan Pengembangan Ekonomi Islam (P3EI) UII Yogyakarta. Ekonomi Islam, ( Jakarta: PT RajaGrafindo Persada, 2008.) 301.

${ }^{3}$ Supriyatno. Ekonomi Mikro Perspektif Islam. (Malang: UIN Malang Press, 2008.) 205.
} 
ekonomi (konsumen, produsen, pemerintah). Dengan kata lain, adanya transaksi pertukaran yang kemudian disebut sebagai perdagangan adalah satu syarat utama dari berjalannya mekanisme pasar. $^{4}$

Mekanisme pasar (market mechanism) adalah kecenderungan di pasar bebas sehingga terjadi perubahan harga sampai pasar menjadi seimbang (equilibrium) yakni sampai jumlah permintaan dan penawaran sama. ${ }^{5}$

Boediono mendefinisikan mekanisme pasar sebagai proses yang berjalan atas dasar gaya (kekuatan) tarik menarik antara konsumen- konsumen (demand) dan produsen-produsen (supply) yang bertemu di pasar. ${ }^{6}$ Dari proses tersebut kemudian terbentuklah suatu harga atas barang di pasar barang dan faktor produksi di pasar faktor produksi.

Pada prinsipnya harga yang dibentuk oleh mekanisme pasar bergerak secara bebas sesuai hukum permintaan dan penawaran. Jika supply lebih besar dari demand, maka harga akan cenderung rendah. Begitupun jika demand lebih tinggi sementara supply terbatas, maka harga akan cenderung mengalami peningkatan.

Mekanisme pasar yang bisa berjalan secara sehat akan dapat membentuk kondisi yang seimbang antara permintaan dan penawaran, yaitu kondisi di mana tidak ada kelebihan ataupun kekurangan stock. Sehingga jumlah barang yang ditawarkan dalam satu periode tertentu sama dengan barang yang diminta. Pada kondisi inilah harga keseimbangan akan terbentuk. ${ }^{7}$

Dalam mekanisme pasar, akan bertemu dua pihak yang saling membutuhkan satu sama lain, yaitu produsen dan pihak konsumen.

Berikut ini akan dipaparkan bagaimana aktivitas produsen dan konsumen menurut pandangan Islam.

\footnotetext{
${ }^{4}$ Karim, Adi Warman. Ekonomi Mikro Islam (Jakarta: IIT Indonesia, 2003) 20

${ }^{5}$ M. Nur Rianto Al Arif dan Euis Amalia, Teori Mikro Ekonomi : Suatu Perbandingan Ekonomi Islam dan Ekonomi Konvensional ( Jakarta : Kencana, 2010), 51

${ }^{6}$ Boediono, Ekonomi Mikro ( Yogyakarta : BPFE UGM, 1982), 8

${ }^{7}$ Brandley R. Schiller, The Micro Economy Today, 58
} 
a) Aktivitas produsen

Pada sistem pasar persaingan bebas, produksi barang didasarkan atas corak permintaan konsumen. Selain itu lazimnya produsen akan selalu berusaha untuk memaksimumkan keuntungannya.

Namun demikian, apabila aktivitas produsen dipengaruhi oleh semangat ruh Islam, maka aktivitasnya dalam memproduksi barang dan mencari keuntungan akan selalu diselaraskan dengan norma-norma yang ada dalam ketentuan syari'at Islam. Pola produksi yang dipengaruhi oleh semangat Islam harus berikut ini: ${ }^{8}$

1) Barang dan jasa yang haram tidak akan diproduksi atau dipasarkan. Maksudnya, pengusaha tidak memproduksi dan memasarkan barang dan jasa yang bertentangan dengan ketentuan syari'at Islam, seperti makanan haram, minuman yang memabukkan.

2) Produksi barang yang bersifat kebutuhan sekunder dan tersier disesuaikan dengan kebutuhan pasar. Dalam hal ini produsen dalam memproduksi barang dan jasa harus mempertimbangkan dengan seksama kemampuan dan kebutuhan masyarakat (dengan tujuan untuk memperoleh untung yang sebesar-besarnya).

3) Produsen hendaklah tetap melakukan control (mempertimbangkan sepenuhnya) permintaan pasar.

4) Dalam proses produksi dan pemasaran harus mempertimbangkan aspek ekonomi, misalnya tidak melakukan produksi dengan biaya tinggi, juga mempertimbangkan mental dan kebudayaan masyarakat, seperti tidak memproduksi barang dan jasa yang merusak mental dan budaya masyarakat.

5) Tidak melakukan penimbunan barang dengan maksud untuk meraih keuntungan yang besar $^{9}$

\footnotetext{
${ }^{8}$ Suhrawardi K. Lubis, Hukum Ekonomi Islam, (Jakarta: Sinar Grafika, 2000), 21

${ }^{9}$ Suhrawardi K. Lubis, Hukum Ekonomi Islam, (Jakarta: Sinar Grafika, 2000), 21
} 
Sedangkan dalam hal mencari/mengejar keuntungan hendaklah selalu mempertimbangkan aspek ekonomi masyarakat. Seorang pengusaha Islam tidak dibenarkan sama sekali dalam melakukan aktivitasnya yang selalu bertumpu kepada tujuan untuk mengejar keuntungan semata. Seorang pengusaha/pedagang dalam pandangan Islam mempunyai tugas untuk menegakkan keadilan dan kebajikan yang diingini oleh agama Islam. Dengan perkataan lain, seorang pengusaha/pedagang Islam juga berkewajiban untuk mendukung dan menguntungkan pihak konsumen. ${ }^{10}$

b) Konsumen

Akan halnya konsumen yang dipengaruhi oleh semangat Islam, pada asasnya konsumen juga berusaha memaksimumkan kepuasannya. Kepuasan yang dimaksud di sini bukanlah kepuasan yang bebas, tetapi kepuasan yang mengacu kepada (dipengaruhi oleh) semangat ajaran Islam.

Dalam ajaran Islam, aspek utama yang dipengaruhi tingkah laku konsumen dalam rangka melakukan permintaan kebutuhan terhadap pasar (yang sekaligus membedakan konsumen yang dipengaruhi oleh semangat Islam dan yang tidak dipengaruhi oleh semangat Islam), adalah yang sebagai berikut:

1) Permintaan pemenuhan kebutuhan terhadap pasar hanya sebatas barang yang penggunaanya tidak dilarang oleh syari'at Islam. Misalnya konsumen tidak mengkonsumsi minuman keras, makanan haram.

2) Cara hidup tidak boros dan kebutuhan terhadap barang konsumsi terlebih dahulu. Dalam ajaran agama Islam prilaku boros merupakan perbuatan yang dilarang, pada dasarnya dalam pandangan Islam, seseorang pemilik harta (individu) tidak mempunyai hak mutlak terhadap harta yang dimilikinya

3) Pemerataan pemenuhan terhadap kebutuhan. Dalam hal ini bagi seseorang muslim yang beruntung memiliki harta, tidaklah mempergunakan harta yang diperolehnya tersebut (yang merupakan titipan untuk pemenuhan

${ }^{10}$ Suhrawardi K. Lubis, Hukum Ekonomi Islam, (Jakarta: Sinar Grafika, 2000), 23 
pribadinya belaka. Sebab didalam harta seorang muslim terdapat hak masyarakat).

4) Dalam aktivitas pemenuhan kebutuhan, konsumen tidak hanya mementingkan kebutuhan yang bersifat materiil semata (tidak berpandangan hidup materialis), tetapi juga kebutuhan yang bersifat immateriil, seperti hak untuk mendapatkan ilmu pengetahuan dan hubunga sosial.

5) Selain memenuhi kepentingan pribadi, juga memperhatikan kepentingan sosial masyarakat.

6) Seorang konsumen juga harus melihat kepentingan konsumen yang lain dan kepentingan pemerintah. Maksudnya seorang konsumen bekerjasama dengan konsumen lain dan pemerintah untuk mewujudkan pembangunan (pembangunan yang Islami)

\section{Mekanisme Pasar Dalm Persepektif Islam}

Konsep pasar yang Islami adalah seperti apa yang dalam ekonomi konvensional disebut dengan pasar persaingan sempurna, yaitu persaingan dalam bingkai nilai dan moralitas Islam. Dengan kata lain pasar ini tidak mengandung deviasi dari nilai dan moralitas Islam. Jadi, jelas bukan pasar bebas dalam arti yang sebebas-bebasnya sebagaimana dalam kapitalisme ${ }^{11}$

1. Islam Dan sistem pasar

Dewasa ini secara umum dapat disampaikan bahwa kemunculan pesan moral Islam dalam pencerahan teori pasar, dapat dikaitkan sebagai bagian dari reaksi penilaian sosialisme dan sekularisme, ataupun secara khusus ideologiideologi yang sudah banyak diasumsikan orang sebagai sistem yang merusak pasar dan memposisikan sebagai oposisi dan pasar bebas dan terbuka didunia Arab.

Oleh sebab itu, sangat utama bagi umat Islam untuk secara kumulatif mencurah semua dukungannya kepada ide keberdayaan, kemajuan, dan kecerahan

\footnotetext{
11 Said Sa'ad Marthon, Ekonomi Islam Ditengah Krisis Global, Terjemahan Ahmad Ikhrom, (Jakarta: Zikrum Hakim, 2004), 107
} 
peradaban bisnis dan perdagangan. Islam secara ketat memacu umatnya dalam aktivitas keuangan dan usaha-usaha meningkatkan kesejahteraan ekonomi dan sosial. Berdagang adalah aktivitas yang paling umum dilakukan di pasar. Untuk itu teks-teks al-Qur'an selain memberikan stimulasi imperative (dorongan )untuk berdagang. Dilain pihak juga mencerahkan aktivitas tersebut dengan sejumlah rambu atau aturan lain yang biasa diterapkan di pasar dalam upaya menegakkan kepentingan semua pihak, baik individu maupun kelompok.

Allah SWT tidak hanya menjamin akses yang memudahkan kaum Quraisy untuk dapat berperan di pasar, bahkan al-Qur'an pun menjabarkan koreksi kepada bangsa Arab yang selama itu salah kaprah dengan meyakini bahwa akan kehilangan kemuliaan dan kekharismaanya bila melakukan kegiatan ekonomi di pasar. Ketika itu bangsa Arab meyakini tidak sepantasnya seorang Nabi mempunyai aktivitas di pasar. ${ }^{12}$

Allah SWT berfirman dalam surat al-Furqan yang berbunyi:
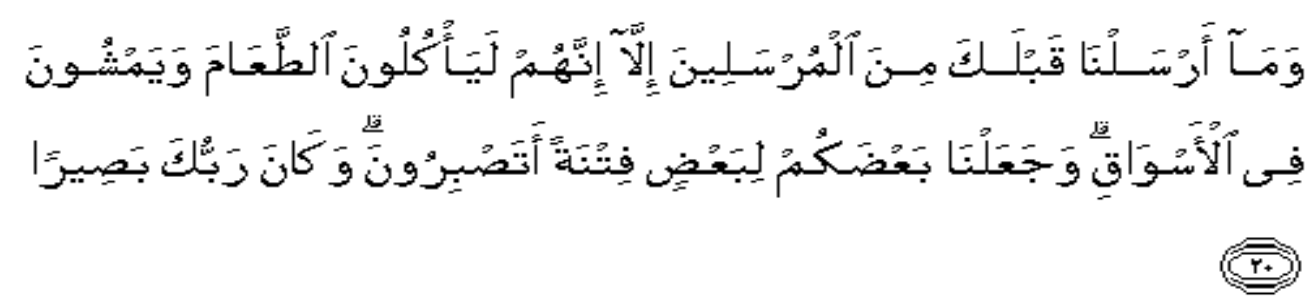

Artinya: "Dan Kami tidak mengutus rasul-rasul sebelummu, melainkan mereka sungguh memakan makanan dan berjalan di pasar- pasar. Dan kami jadikan sebahagian kamu cobaan bagi sebahagian yang lain. Maukah kamu bersabar?; dan adalah Tuhanmu maha Melihat". (Qs. Al-Fur'qan ayat 20)

Dalam konsep ekonomi Islam harga ditentukan oleh keseimbangan permintaan dan penawaran. Keseimbangan ini tidak terjadi bila antara penjual dan pembeli tidak bersikap saling merelakan. Kerelaan ini ditentukan oleh penjual dan pembeli dalam mempertahankan kepentingannya atas barang tersebut. Jadi, harga ditentukan oleh kemampuan penjual untuk menyediakan barang yang ditawarkan

12 Mustafa Edwin Nasution, Dkk, Panganalan Eksklusif Ekonomi mIslam, (Jakarta: Kencana, 2006), 157 
kepada pembeli, dan kemampuan pembeli untuk mendapatkan barang tersebut dari penjual.

Dalam ekonomi Islam keseimbangan pasar mempertimbangkan beberapa hal $::^{13}$

a. Dalam konsep Islam monopoli, duopoli, oligopoli tidak dilarang keberadaannya selama mereka tidak mengambil keuntungan di atas keuntungan normal. Ini merupakan konsekuensi dari konsep keseimbangan harga. Produsen yang beroperasi dengan posisi untung akan mengundang produsen lain untuk masuk kedalam pasar yang sama sehingga jumlah output yang ditawarkan bertambah, dan harga akan turun. Produsen baru akan memasuki bisnis tersebut sampai dengan harga turun sedemikian sehingga keuntungan ekonomi habis. Pada keadaan ini produsen yang telah ada di pasar tidak mempunyai insentif untuk keluar dari pasar, dan produsen yang belum masuk ke pasar tidak mempunyai intensif untuk masuk ke pasar.

b. Kondisi pasar yang kompetitif mendorong segala sesutunya menjadi terbuka.

c. Produsen dilarang melakukan praktek perdagangan demi keuntungan pribadi dengan cara menjemput pedagang di pinggir kota, mendapatkan keuntungan dari ketidaktahuan penjual dari suatu kota terhadap harga yang berlaku di kota lain.

d. Konsep Islam melarang penimbunan karena alasan untuk mencari keuntungan dari kalangan barang di pasar.

e. Islam melarang kaum muslimin untuk bertindak curang.

f. Menyembunyikan barang cacat karena penjual mendapatkan harga yang tinggi.

g. Jual beli dilakukan dengan keadaan nilai barang yang sama ${ }^{14}$

${ }^{13}$ Heri Sudarsono, Konsep Ekonomi Islam Suatu Pengantar, (Yogyakarta: Ekonosia,2004),216

${ }^{14}$ Heri Sudarsono, Konsep Ekonomi Islam Suatu Pengantar, (Yogyakarta: Ekonosia,2004),218 
2. Harga dan persaingan sempurna pada pasar Islami

Berdasarkan kebutuhan efektif, yang bekerja melalui kekuatan kebutuhan dan penawaran (supplay) dan yang bersifat pribadi dan tidak kelihatan dengan sumber kekayaan yang dapat membelinya dan bukan bagi orang yang memerlukannya, dan bahwa pasar itu tidak efisien, tidak efektif atau sama saja dalam melengkapi semua segi dari kebutuhan pokok yang berhubungan dengan pasar menurut Islam.

Dengan demikian harga yang ditawarkan oleh pasar secular tidak terlihat sebagai petunjuk kesejahteraan sosial, teristimewa menurut ekonomi Islam dimana rasa sosial yang begitu besar untuk melakukan pembagian sebagai kunci aktivitas yang produktif. Persaingan tersembunyi dalam mekanisme pasar harus melengkapi dengan pengendalian, pengawasan, dan kerja sama yang seksama.

Keengganan orang Islam untuk menerima harga pasar sebagai sarana menuju kesejahteraan sosial menurut fungsi dari kelenturan harga kebutuhan dan supplay menurut kebiasaan jadi terbatas. Reaksi keperluan akan perubahan dalam pemasukan dipandang sebagai hal yang lebih penting daripada harga dalam ekonomi Islam. Kewajiban yang utama dalam analisis ekonomi Islam adalah menganalisis faktor-faktor atau kekuatan kekuatan pasar yang mempengaruhi asal usul dan supplay

Konsep Islam memahami bahwa pasar dapat berperan efektif dalam kehidupan ekonomi bila prinsip persaingan bebas dapat berlaku secara efektif. Pasar tidak mengharapkan adanya intervensi dari pihak manapun, tak terkecuali negara dengan otoritas penentuan harga atau privat sector dengan kegiatan monopolistik ataupun yang lainnya.

Karena pada dasarnya pasar tidak membutuhkan kekuasaan yang besar untuk menentukan apa yang harus dikonsumsi dan diproduksi. Sebaliknya, biarkan tiap individu dibebaskan untuk memilih sendiri apa yang dibutuhkan dan bagaimana memenuhinya. Inilah pola normal pasar atau "keteraturan alami" dalam 
istilah al-Ghozali menyatakan serahkan saja pada invisible hand (tangan tak terlihat) dan dunia akan teratur dengan sendirinya

Dengan perkataan lain, menurut Adam Smith, apabila pemerintahan tidak secara aktif terlibat dalam mempengaruhi kegiatan ekonomi maka perekonomian tersebut akan dengan sendirinya mengatur dan membuat penyesuaian di dalam berbagai aspek kehidupan ekonomi. Pengaturan yang bebas dari campur tangan pemerintahan tersebut akan mewujudkan kegiatan ekonomi yang efisien.

\section{Mekanisme Pasar Pemikiran Abu Yusuf}

Mekanisme Pasar berarti cara kerja pasar yang merupakan sarana penyediaan kebutuhan-kebutuhan hidup dan sekaligus tempat para konsumen dan produsen mengadakan transaksi jual beli. ${ }^{15}$

Menurut Abu Yusuf sistem Ekonomi Islam seharusnya mengikuti prinsip mekanisme pasar dengan memberikan kebebasan yang optimal bagi para pelaku di dalamnya, yaitu produsen dan konsumen. Dalam konsep ekonomi Islam penentuan harga dilakukan oleh kekuatan-kekuatan pasar, yaitu kekuatan permintaan dan kekuatan penawaran. Dalam konsep Islam, pertemuan permintaan dengan penawaran tersebut haruslah terjadi secara rela sama rela, tidak ada pihak yang merasa terpaksa untuk melakukan transaksi pada tingkat harga tersebut.

Di samping pengertian-pengertian yang disebutkan di atas ada juga yang mengartikan pasar sebagai berikut: Pasar adalah waktu dan tempat umum yang digunakan untuk membeli dan menjual barang dan jasa dan ada juga yang menerjemahkan sebagai tempat atau rangkaian keadaan-keadaan yang mengumpulkan para pembeli dan penjual, baik berhadapan muka satu sama lain, ataupun melalui suatu alat penghubung, baik secara langsung, maupun melalui perantaraan agen,

\footnotetext{
${ }^{15}$ Hamzah Ahmad dan Ananda Santoso, Kamus Pintar Bahasa Indonesia, (Surabaya: Fajar Mulya, 1996), 250
} 
pedagang perantara dan seterusnya untuk melaksanakan pembelian, penjualan atau pertukaran barang dan jasa. ${ }^{16}$

Pasar tidak hanya sebagai tempat bertemu penjual dan pembeli yang saling bertatap muka untuk melakukan transaksi jual beli produk baik barang maupun jasa. Namun transaksi ini dapat juga melalui perantara seperti melalui sarana elektronik seperti telepon, faksimili atau melalui internet. Pasar juga merupakan kumpulan atau himpunan dari para pembeli, baik pembeli nyata maupun pembeli potensial atas suatu produk atau jasa tertentu. Pasar juga mengadung arti adanya kekuatan permintaan dan penawaran terhadap suatu produk.

Abu Yusuf memperhatikan peningkatan dan penurunan produksi dalam kaitanya dengan perubahan harga. Pemahaman saat itu mengatakan bahwa bila tersedia sedikit barang, maka harga akan mahal dan bila tersedia banyak barang maka harga akan murah. Gambaran grafis dari pernyataan tersebut adalah: ${ }^{17}$

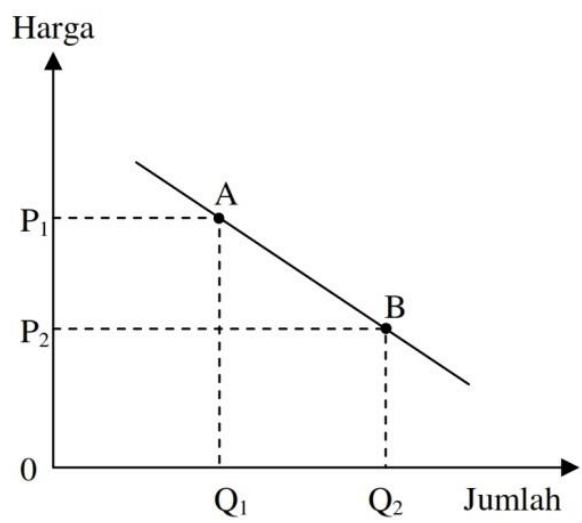

Pemahaman pada zaman Abu Yusuf di atas tentang hubungan antara harga dan kuantitas hanya memperhatikan kurva permintaan.

Dalam literatur kontemporer fenomena yang berlaku pada masa Abu Yusuf dapat dijelaskan dengan teori permintaan. Teori ini menjelaskan hubungan antara harga dengan banyaknya kuantitas yang diminta.

${ }^{16}$ Ensiklopedi, Ekonomi Keuangan Perdagangan, (Jakarta: Pradnya Parawita, 1980),656.

${ }^{17}$ Adiwarman Karim, Ekonomi Mikro Islami, (Jakarta: PT, Raja Grafindo Persada,2004),120 
Apabila $\mathrm{P} \downarrow$ (turun) maka $\mathrm{Q} \uparrow$ (naik) begitu sebaliknya apabila $\mathrm{P} \uparrow($ naik) maka $\mathrm{Q} \downarrow$ (turun) . dari formulasi ini kita dapat menyimpulkan bahwa hukum permintaan menyatakan bila harga komoditi naik maka akan direspon oleh penurunan jumlah komoditi yang dibeli. Begitu juga apabila harga komoditi turun maka akan direspon oleh konsumen dengan meningkatkan jumlah komoditi yang dibeli. ${ }^{18}$

Bila tersedia sedikit barang (Q1) harga akan naik P1 sehingga terjadi kombinasi titik A, sebaliknya bila tersedia banyak barang (Q2) harga akan turun pada P2 sehingga terjadi kombinasi titik B.

Abu Yusuf membantah pemahaman yang seperti ini, karena pada kenyataannya persediaan barang sedikit tidak selalu diikuti dengan kenaikan harga. Dan sebaliknya persediaan barang melimpah belum tentu membuat harga akan murah. ${ }^{19}$

Namun demikian ada hal menarik dari apa yang pernah disampaikan Abu Yusuf dalam kitab Al-Kharaj bahwa mahal atau murahnya suatu komoditas tidak bisa ditentukan secara pasti, dimana murah bukan karena melimpahnya barang tersebut dan mahal bukan karena kelangkaannya. ${ }^{20} \mathrm{Hal}$ ini dinyatakan melalui statement beliau “ mahal dan murah merupakan ketentuan Allah, terkadang makanan melimpah tetapi harga mahal dan terkadang makanan sedikit tapi tetap murah". ${ }^{21}$

Hal ini dapat digambarkan sebagai berikut:

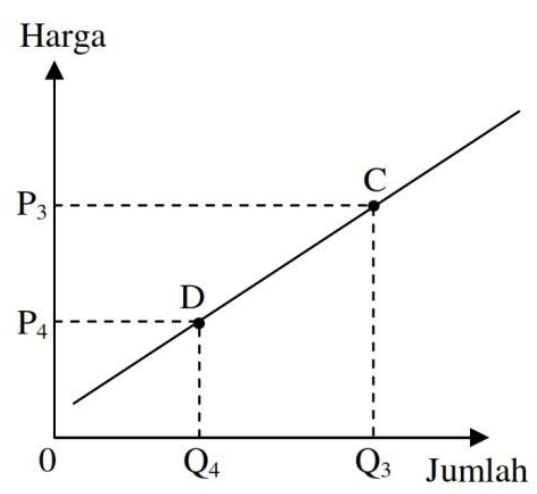

\footnotetext{
${ }^{18}$ Adiwarman Karim, Ekonomi Mikro Islami, (Jakarta: PT, Raja Grafindo Persada,2004),250

${ }^{19}$ Adiwarman Karim, Ekonomi Mikro Islami, (Jakarta: PT, Raja Grafindo Persada,2004),121

20 Mustafa Edwin Nasution, Dkk, Panganalan Eksklusif Ekonomi mIslam, (Jakarta: Kencana, 2006), 167.

${ }^{21}$ Abu Yusuf, Kitab al-Kharaj, (Bairut: al-Ma'rifah, 1979),48.
} 
Menurut Abu Yusuf dapat saja harga-harga tetap mahal (P3) ketika persediaan barang melimpah (Q3), sementara harga akan murah walaupun persediaan barang berkurang (Q4). Dari pernyataan tersebut di atas tampaknya Abu Yusuf menyangkal pendapat umum mengenai hubungan terbalik antara persedian barang (supply) dan harga karena pada kenyataannya harga tidak bergantung pada permintaan saja, tetapi juga bergantung pada kekuatan penawaran. Oleh karena itu peningkatan atau penurunan harga tidak selalu berhubungan dengan peningkatan atau penurunan permintaan. $^{22}$

Titik C menggambarkan keadaan persediaan barang melimpah (Q3) sementara harganya tinggi (P3). Pada titik D terjadi sebaliknya yakni persediaan barang relatif sedikit (Q4) tetapi harganya rendah (P4).

Dari penjelasan di atas kita dapat menyimpulkan bahwa hokum penawaran mengatakan bila harga komoditi naik maka akan direspon oleh penambahan jumlah komoditi yang ditawarkan. Begitu juga apabila harga komoditi turun akan direspon oleh penurunan jumlah komoditi yang ditawarkan. ${ }^{23}$ Abu Yusuf mengatakan,

$$
\begin{aligned}
& \text { والرخص وللغلاء يد الله تعالى لايقومان على امر وحد. وكذلك وظفية الد راهم مع } \\
& \text { اسياء كثيرة تدخل فن ذلك تفسير ها يطول، وليس الرخص ولغلاء حد يمر ف ولا } \\
& \text { يقام عليه انما هو امر من العياء لايدرى كيف هو. وليس الرخض من كثرة الطعام } \\
& \text { ولا غلاؤ من قلته، انما ذلك أمره الله وتضاؤه، وقدبكون الطعام كثيرا غاليا، } \\
& \text { وقديكون قليلا رخيما. }
\end{aligned}
$$

\footnotetext{
${ }^{22}$ Adiwarman Karim, Ekonomi Mikro Islami, (Jakarta: PT, Raja Grafindo Persada,2004),121
}

${ }^{23}$ Adiwarman Karim, Ekonomi Mikro Islami, (Jakarta: PT, Raja Grafindo Persada,2004),20 
Artinya : "Tidak ada batasan tertentu tentang murah dan mahal yang dapat dipastikan. Hal tersebut ada yang mengaturnya. Prinsipnya tidak bisa diketahui. Murah bukan kerena melimpahnya makanan, demikian juga mahal tidak disebabkan karena kelangkaan makanan. Murah dan mahal merupakan ketentuan Allah (Sunnatullah). Kadang-kadang makanan sangat sedikit, tetapi harganya murah". ${ }^{24}$

Dari sini dapat dipahami bahwa Abu Yusuf menegaskan ada beberapa variabel lain yang berlaku disini, yang bukan hanya karena hukum permintaan dan penawaran. Atau dengan kata lain peningkatan atau penurunan harga tidak selalu berkaitan dengan penurunan dan peningkatan produksi. Bisa jadi karena adanya distorsi pada distribusi, yang disengaja untuk merusak daya beli masyarakat pada kondisi pasar normal dan terbuka, seperti terjadinya penimbunan barang ataupun lainnya. Untuk itu pada kondisi ini, negara dapat berperan sebagai pengawas atau regulator yang menjamin kebebasan, kesempurnaan dan keterbukaan pasar. ${ }^{25}$

Abu Yusuf mengatakan bahwa setiap benda yang apabila ditahan (ditimbun) menyebabkan gangguan bagi manusia adalah monopoli. Semakin meningkat kebutuhan orang terhadap barang tersebut semakin besar pula dosa orang yang memonopolinya, terutama adalah bahan makanan, terutama lagi bahan pokok yang mendesak. ${ }^{26}$

Abu Yusuf menentang penguasa yang menetapkan harga. Hasil panen yang berlimpah bukan alasan untuk menurunkan harga panen dan sebaliknya kelangkaan tidak mengakibatkan harganya melambung. Fakta di lapangan menunjukan bahwa ada kemungkinan kelebihan hasil dapat berdampingan dengan harga yang tinggi dan kelangkaan dengan harga yang rendah. ${ }^{27}$

\footnotetext{
${ }^{24}$ Abu Yusuf, Kitab al-Kharaj, (Bairut: al-Ma'rifah, 1979), 48.

${ }^{25}$ Mustafa Edwin Nasution, Dkk, Panganalan Eksklusif Ekonomi mIslam, (Jakarta: Kencana, 2006), 167.

${ }^{26}$ Yusuf Qardawi, Norma Dan Etika Dalam Ekonomi Islam, (Jakarta: Gema Insani Press, 1997),191.

${ }^{27}$ Heri Sudarsono, Konsep Ekonomi Islam Suatu Pengantar, (Yogyakarta: Ekonesia,2002),150.
} 
Argumennya didasarkan pada hadits Rasullullah SAW sehubungan dengan adanya kenaikan harga-harga barang:

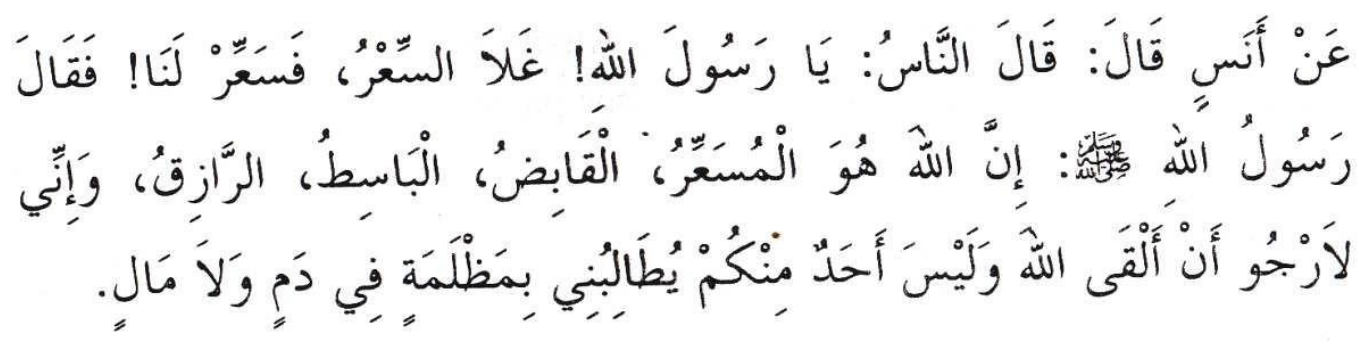

Artinya: Dari Anas, ia berkata: Orang-orang berkata, "Wahai Rasulullah, harga telah naik, maka tetapkanlah harga untuk kami”. Lalu Rasulullah SAW bersabda, "sesungguhnya Allah yang menetapkan harga, yang mempersempit, dan memperluas, dan aku berharap bertemu dengan Allah sedangkan salah seorang dari kalian tidak menuntutku karena kezhaliman dalam darah atau harta”

Dapat diketahui bahwa para penguasa pada periode itu umumnya memecahkan masalah kenaikan harga dengan menambah suplai bahan makanan dan mereka menghindari kontrol harga. Kecenderungan yang ada dalam ekonomi Islam adalah membersihkan pasar dari praktik penimbunan, monopoli, dan praktik korup lainya dan kemudian membiarkan penentuan harga kepada kekuatan permintaan dan penawaran. Abu Yusuf tidak dikecualikan dalam hal kecenderungan ini.

\section{Kesimpulan}

Mekanisme Pasar dalam perkembangan Ekonomi sudah banyak terjadi inovasi yang dilakukan oleh para tokoh tokoh ekonomi modern. Dalam hal ini mekanisme pasar yang berkembang banyak terajadi perbedaan antara mekanisme modern dengan mekanisme pemikiran ekonomi Islam, dimana para pemikir ekonomi Islam lebih dulu memperkenalkan mekanisme pasar terlebih oleh pemikir ekonmi islam Abu Yusuf, tercatat merupakan ulama terawal yang mulai menyinggung mekanisme pasar.

Dalam hal mekanisme pasar Abu Yusuf memberikan pandangan yang berbeda dengan pendapat umum, dimana harga mahal bukan berarti terdapat 
kelangkaan barang dan harga yang murah bukan berarti jumlah barang melimpah, tetapi ada variabel lain yang menentukan pembentukkan harga.

Abu Yusuf juga menentang penguasa menetapkan harga. Namun Beliau juga membolehkan intervensi harga di pasar dalam keadaan tertentu. Abu Yusuf mengatakan bahwa tingkat harga tidak hanya bergantung pada permintaan semata namun juga pada kekuatan penawaran. Oleh karena itu, kenaikan atau penurunan tingkat harga tidak harus selalu berhubungan dengan kenaikan dan penurunan produksi saja.

\section{Daftar Pustaka}

Abu Yusuf, Kitab Al-Kharaj, Beirut: Dar al-Ma'rifah, 1979.

Ahmad,Hamzah dan Ananda Santoso, Kamus Pintar Bahasa Indonesia. Surabaya: Fajar Mulya, 1996

Boediono, Ekonomi Mikro. Yogyakarta: BPFE UGM, 1982.

Departemen Agama RI, Al-Qur'an Dan Terjemahnya. Bandung: Rajawali Pers, 2005.

Ensiklopedi, Ekonomi Keuangan Perdagangan. Jakarta: Pradnya Parawita, 1980.

Edwin Nasution, Mustafa Dkk, Panganalan Eksklusif Ekonomi Islam, Jakarta: Kencana, 2006.

Karim A. Adiwarman, Ekonomi Mikro Islami, Jakarta: PT. Raja Grafindo Persada, 2007

Karim A. Adiwarman Sejarah Pemikiran Ekonomi Islam. Jakarta: PT. Raja Grafindo Persada, 2004.

Mawardi, Ekonomi Islam. Pekanbaru: Alaf Riau Graha UNRI PRESS, 2007.

Nur,M. Rianto Al Arif dan Euis Amalia, Teori Mikro Ekonomi : Suatu Perbandingan Ekonomi Islam dan Ekonomi Konvensional. Jakarta: Kencana, 2010.

Sudarsono, Heri, Konsep Ekonomi Islam Suatu Pengantar. Yogyakarta: Ekonesia, 2002.

Qardawi, Yusuf, Norma Dan Etika Dalam Ekonomi Islam. Jakarta: Gema Insani Press, 1997. 